\title{
ANALISIS ELEMEN-ELEMEN FRAUD PENTAGON SEBAGAI DETERMINAN FRAUDULENT FINANCIAL REPORTING
}

\author{
Khusnatul Zulfa ${ }^{1)}$, Amira Bayagub ${ }^{2)}$ \\ ${ }^{1}$ Fakultas Ekonomi, Universitas Muhammadiyah Ponorogo \\ khusnafeump@gmail.com \\ ${ }^{2}$ Fakultas Ekonomi, Universitas Muhammadiyah Ponorogo \\ bayagubamira@gmail.com
}

\begin{abstract}
This study aims to examine the influence of externalxpressure, institutionalownership, $x$ financial stability, xquality of external auditor, xchange inxauditor, change in director and frequentxnumber of CEO's picture on the fraudulent financial reporting among the property and real estate firms listed in Indonesia stock exchange during 2014-2016. The data used in this study is secondary data obtained from the firms' annual report which was accessed through www.idx.co.id. The data analysis method used in this study is multiple linear regression analysis. SPSS ver 2.0 was used to analyze the data. The samples were selected using a non-probability sampling technique with a purposive sampling method and obtained a sample of 41 property and real estate companies during 2014-2016. The results of variable test indicates that external pressure and change in director partially influences fraudulent financial reporting, while institutional ownership, financial stability, quality of external auditor, change in auditor, and frequent number of CEO's picture partially does not influence fraudulent financial reporting. The Simultaneous test shows that external pressure, institutional ownership, financial stability, quality of external auditor, change in auditor, change in director and frequent number of CEO's picture
\end{abstract}

Keywords: External Pressure, Institutional Ownership, Financial Stability, Quality of External Auditor, Change in Auditor, Change in Director, Frequent Number of CEO's Picture, Fraudulent Financial Reporting.

\section{PENDAHULUAN}

Laporan keuangan sebagai alat pertanggungjawaban yang berisi informasi tentang data keuangan dan aktivitas operasional sebagai instrumen penting dalam perusahaan untuk memberikan informasi kepada pihak-pihak yang mempunyai kepentingan (stakeholder), namun kadang kala tujuan laporan keuangan tersebut lebih dominan untuk terlihat baik dari berbagai pihak. Adanya keinginan untuk terlihat baik oleh berbagai pihak inilah yang mendorong perusahaan melakukan kecurangan laporan keuangan.

Kecurangan-kecurangan yang dilakukan perusahaan untuk memanipulasi laporan keuangan sering disebut disebut dengan fraud, dan praktik kecurangan 
pelaporan keuangan itu sendiri dikenal dengan fraudulent financial reporting. Fraudulent Financial Reporting merupakan suatu usaha yang dilakukan dengan sengaja oleh perusahaan untuk mengecoh dan menyesatkan para pengguna laporan keuangan terutama investorndan kreditur, dengan menyajikan dan merekayasa nilai material dari laporan keuangan (Sihombing dan Rahardjo, 2014).

Fraudulent Financial Reporting sampai saat ini masih menjadi permasalahan yang tidak bisa diremehkan karena dari tahun ke tahun kasus terjadinya fraud selalu ditemukan dalam laporan keuangan. Dalam mencegah kemungkinan terjadinya fraud, auditor dapat menilai dan mempertimbangkan dari berbagai perspektif salah satunya dengan menggunakan pengujian teori fraud pentagon yang dikemukakan oleh Crowe (2011) yang terdiri dari lima elemen indikator di dalamnya yaitu: Pressure, Opportunity, Rationalization, Capability, dan Arrogance. Lima elemen tersebut merupakan teori terbarukan yang sebelumnya diungkapkan oleh Cressey (1953) yaitu fraud triangle theory dan yang diungkapkan oleh Wolfe dan Hermanson (2004) dengan fraud diamond theory.

Dalam penelitian ini mengimplementasikan teori dari crowe (2011) yaitu Crowe's Fraud Pentagon Theory yang muncul karena faktor-faktor Pressure yang diproksikan dengan external pressure, institusional ownership dan financial stability, dimana ketiganya dapat mendorong manajer dalam melakukan fraudulent financial reporting karena adanya tekanan yang berlebihan yang dialami manajer. Opportunity diproksikan dengan kualitas auditor eksternal yang mana setiap manajer akan mempunyai kesempatan untuk melakukan fraudulent financial reporting. Rationalization diproksikan dengan change in auditor, yang membuat manajer merasionalisasikan apa yang dilakukan dalam fraudulent financial reporting. Sedangkan capability diproksikan dengan perubahan direksi yang mengakibatkan stress period bagi seorang manajer, sehingga memiliki kemampuan dalam melakukan fraudulent financial reporting dan Arrogance diproksikan dengan frequent number of CEO's picture dimana frequent number of CEO's picture diindikasikan dapat mengakbatkan fraudulentzfinancial reporting.

Penelitian Chyntia G. Tessazzet al menyimpulkan bahwa External Pressure dan frequent number of CEO's picture berpengaruh terhadap Fraudulent 
Financial Reporting sedangkan penelitian Ema Harviana menyimpulkan bahwa External Pressure dan Frequent Number of CEO's Picture tidak berpengaruh terhadap Fraudulent Financial Reporting. Adanya ketidakkonsistenan dari penelitian terdahulu, menjadi alasan untuk melakukan pengujian kembali. Maka dari itu, penelitian ini diambil berlandaskan oleh berbagai fenomena diatas dan latar belakang yang telah diuraikan tentang fraudulent financial reporting dengan judul "Analisis elemen-Elemen Fraud Pentagon sebagai Determinan Fraudulent Financial Reporting”.

Tujuan penelitian adalah untuk mengetahui pengaruh External Pressure Terhadap Fraudulent Financial Reporting. Untuk mengetahui pengaruh Institusional Ownership terhadap Fraudulent Financial Reporting. Untuk mengetahui pengaruh Financial Stability terhadap Fraudulent Financial Reporting. Untuk mengetahui pengaruh Kualitas Auditor Eksternal Terhadap Fraudulent Financial Reporting. Untuk mengetahui pengaruh Changenin Auditor Terhadap Fraudulent Financial Reporting. Untuk mengetahui pengaruh Perubahan Direksi Terhadap Fraudulent Financial Reporting. Untuk mengetahui pengaruh Frequent Number of CEO's Picture terhadap Fraudulent Financial Reporting. Untuk mengetahui pengaruh External Pressure, Institusional Ownership, Financial Stability, Kualitas Auditor Eksternal, Change in Auditor, Perubahan Direksi, dan Frequent Number of CEO's Picture Terhadap Fraudulent Financial Reporting.

\section{TELAAH LITERATUR DAN PENGEMBANGAN}

\section{Agency Theory (Teori Keagenan)}

Teori keagenan (agency theory) menjelaskan adanya hubungan kerjasama antar pihak pemegang saham sebagai principal dan manajemen sebagai agent. Hubungan agensi ada ketika salah satu pihak (principal) yang alam hal ini adalah pemilik perusahaan atau pemegang saham menyewa oranglain (agent) yaitu manajemen perusahaan untuk melakukan suatu jasa dan para principal 
mendelegasikan wewenang kepada agennya untuk membuat keputusan (Jensen dan Meckling, 1976)."

\section{Fraud}

Fraud secara umumndiartikan sebagai kecurangan yang sengaja dilakukan. Fraud menimbulkan kerugian bagi pihak lain dan memberikan keuntungan bagi pelaku kecurangan dan atau kelompoknya (Suyanto, 2009).

\section{Teori Fraud Triangle}

Teori fraud triangle merupakan teori pertama yang mampu menjelaskan elemen-elemen penyebab fraud yangzdikenal dengan konsep segitiga kecurangan. Teori ini dikemukakan oleh Cressey pada tahun 1953 yang berpendapat bahwa sampai batas tertentu terdapat tiga kondisi yang selalu mempengaruhi terjadinya kecurangan laporan keuangan. Kondisi ini terdiri dari pressure, opportunity, dan rationalization.

\section{FraudIDiamond Theory}

Fraud diamond theory pertama kali dikenalkan oleh Wolfe dan Hermanson pada bulan Desember 2004. Hal inindipandang sebagai penyempurnaan yang diperluas dari fraud triangle theory. Wolfe dan Hermanson (2004) zmengatakan: Banyak kecurangan tidak akan terjadi tanpa adanya orang yang tepat yang memilikinkemampuan untuk melakukan kecurangan. Posisi seseorang atau fungsindalam organisasindapat memberikan kemampuan untuk membuat atau memanfaatkan kesempatan agar kecurangan tidak tersedia untuk orang lain"."Dari pernyataan tersebut dapat dikatakan bahwa variabel kemampuan (capability) dapat dijadikan sebagai salah satu faktor yang mempengaruhi seseorang melakukan fraud di lingkungan organisasi. Fraud diamond ini terdiri dari empat elemen indikator yaitu tekanan (pressure), kesempatan (opportunity), rasionalisasi (rationalization) dan kemampuan (capability). 


\section{Fraud Pentagon Theory}

"Teori terbarukan yang mengupas lebih mandalam mengenai faktor-faktor pemicu fraud adalah teorinfraud pentagon (Crowe's fraud pentagon theory). Teori ini dikemukakan oleh Crowen Howart pada tahun 2011. Teori fraud pentagon merupakan perluasan dari teori fraud triangle yang sebelumnya dikemukakan oleh Cressey 1953, dan teori fraudndiamond yang sebelumnya dikemukakan oleh Wolfe dan Hermanson 2004, dalam teori ini menambahkan satu elemen fraud yaitu arogansi (arrogance). Sehingga dalam fraud model yang ditemukan olehnCrowe terdiri dari lima elemen indikator yaitu tekanan (pressure), kesempatan (opportunity), rasionalisasi (rationalization), kemampuan (capability), dan arogansi(arrogance)."

\section{Fraudulent Financial Reporting (Kecurangan Pelaporan Keuangan)}

Menurut Association of Certified Fraud Examinersz (ACFE), fraudulent financial reporting adalah fraud yang dilakukan oleh manajemen dalam bentuk salah saji materialnlaporan keuangan yang merugikan investor dannkreditur. Pelaporan keuangan yang mengandung unsur fraud dapat mengakibatkan turunnya integritas informasi keuangan dan membuat investor salah dalam mengambil keputusan.

Elemen-elemen dalam Crowe's pentagon theory ini tidakndapat begitu saja diteliti sehingga membutuhkan proksi variabel. Proksi yang dapat digunakan untuk penelitian ini antara lainn pressure yang diproksikan dengan external pressure, institusional ownership dan financial stability. Opportunity yang diproksikan dengan kualitas auditor eksternal. Rationalization yang diproksikan dengan change in auditor. Capability yang diproksikan dengan perubahan direksi. Dan Arrogance diproksikan dengan frequent number of CEO's picture." 
Maka dapat digambarkan dalam kerangka berfikir sebagai berikut :

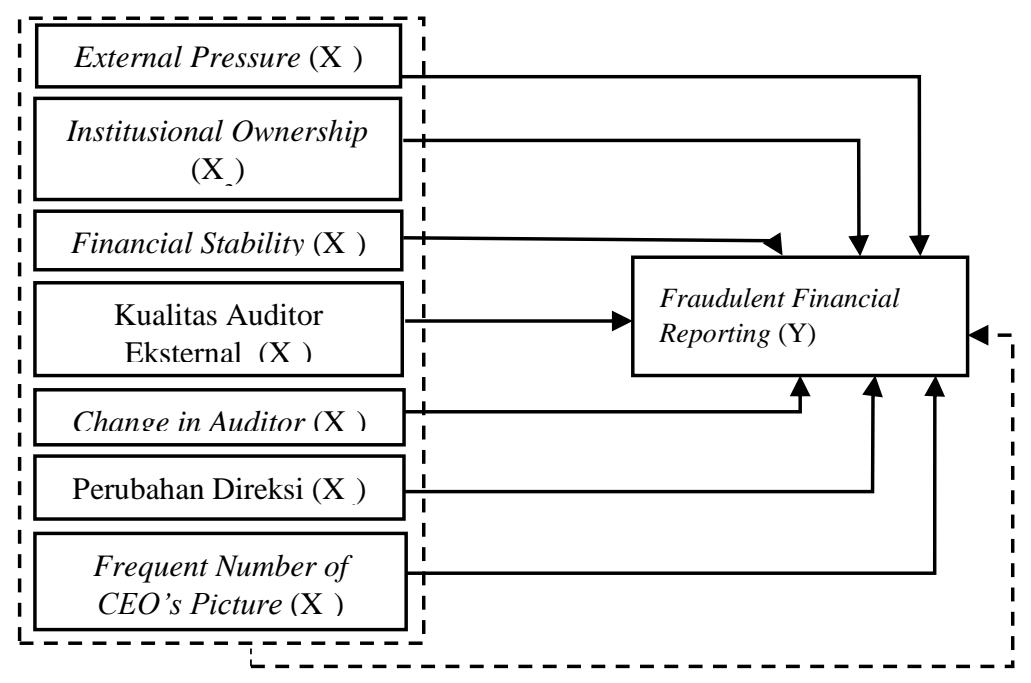

Gambar 1.

Kerangka Pikir

\section{METODE PENELITIAN}

Penelitian ini menggunakan metode kuantitatif untuk menganalisis hubungan antara variabel independen yang merupakan elemen fraudnpentagon dengan kecurangan pelaporan keuangan (fraudulentn financial reporting). Pertimbangan penggunaan metode kuantitati dalam penelitian ini dikarenakan penelitian ini menggunakan angka-angka sebagai indikator variabel penelitian untuk menjawab permasalahan yang akan diteliti. Jenis data penelitian adalah data sekunder.

Data yang digunakan dalam penelitian ini berupa data laporan tahunan perusahaan yang didapat dari situs resmi Bursa Efek (www.idx.co.id) dan laporan tahunan dari situs resmi website perusahaan dalam kurun waktu 2014-2016.

Populasi dalam penelitian ini adalah perusahaan keseluruhan perusahaan property dan real estate yang terdaftar di Bursa Efek Indonesia tahun 2014-2016 sebanyak 58 perusahaan yang terdiri dari sub sektor property dan real estate sebanyak 47 perusahaan dan sub sektor building construction sebanyak 11 perusahaan.

Pengambilan sampel dalam penelitian ini yaitu menggunakan metode purposive sampling yaitu metode pemilihan objek dengan beberapa kriteria 
tertentu, sehingga diperoleh sampel yang representatif sesuai dengan kriteria yang ditentukan. Kriteria yang dimaksudkan adalah sebagai berikut:

1. Perusahaan mempublikasikan laporan tahunan dalam website perusahaan atau website BEI (www.idx.co.id) selama periode 2014-2016.

2. Perusahaan yang tidak delisting dari BEI selama periode pengamatan 20142016."

3. Data-data yang berkaitan dengan variabel penelitian tersedia dengan lengkap dalam laporan tahunan selama periode 2014-2016.

Berdasarkan karakteristik sampel dari 58 perusahaan terdapat 41 perusahaan yang memenuhi karakteristik sebagai sampel penelitian ini. Metode analisis data dalam pengujian ini adalah Uji Asumsi Klasik, Regresi Linear Berganda, Uji Koefisien Determinasi, Uji Parsial, dan Uji Simultan.

\section{HASIL DAN PEMBAHASAN}

\section{Analisis Data}

Adanya perbedaan satuan dan besaran variabel bebas dan variabel terikat maka seluruh data harus disamakan satuannya dengan menggunakan model logaritma natural (Ln). Karena adanya langkah model logaritma natural maka sampel penelitian ini berkurang dan total sampel adalah 46 .

\section{Uji Asumsi Klasik}

\section{a. Uji Normalitas}

Tabel 1

Uji Normalitas

One-Sample Kolmogorov-Smirnov Test

\begin{tabular}{|c|c|c|}
\hline & & $\begin{array}{c}\text { UnstandardizedResi } \\
\text { dual }\end{array}$ \\
\hline \multicolumn{2}{|l|}{$\mathrm{N}$} & 46 \\
\hline \multirow{2}{*}{ Normal Parameters ${ }^{a, b}$} & Mean & 0E-7 \\
\hline & $\begin{array}{l}\text { Sta. Deviation } \\
\text { Absolute }\end{array}$ & $\begin{array}{r}1.00015021 \\
.100\end{array}$ \\
\hline MostExtreme Differences & Positive & .056 \\
\hline & Negative & -.100 \\
\hline Kolmogorov-Smirnov Z & & .681 \\
\hline Asymp. Sig. (2-tailed) & & .742 \\
\hline
\end{tabular}

a. Test distribution is Normal.

b. Calculated from data.

Suumber : Output SPSS diolah, 2018 
Berdasarkan tabel output SPSS terlihat bahwa nilai sig (2-tailed) sebesar $0,742>0,05$, sehingga dapat disimpulkan bahwa keseluruhan sampel dalam penelitian ini berasal dari populasi yang berdistribusi normal.

\section{b. Uji Multikolinieritas}

Hasil perhitungan nilai tolorance $>0,10$ dan perhitungan VIF juga memiliki nilai <10. Dapat disimpulkan tidak ada multiko-linearitas antar variabel independen.

Tabel 2

Uji Multikolonieritas

\begin{tabular}{|c|c|c|c|c|c|c|c|c|}
\hline \multicolumn{9}{|c|}{ Coefficients $^{\circ}$} \\
\hline \multirow[t]{2}{*}{$\overline{\operatorname{Mod}}$} & & \multicolumn{2}{|c|}{$\begin{array}{l}\text { Unstandardized } \\
\text { Coefficients }\end{array}$} & \multirow{2}{*}{\begin{tabular}{c|}
$\begin{array}{c}\text { Standardized } \\
\text { Coefficients }\end{array}$ \\
Beta
\end{tabular}} & \multirow[t]{2}{*}{$t$} & \multirow[t]{2}{*}{ Sig. } & \multicolumn{2}{|c|}{ Collinearity Statistics } \\
\hline & & $B$ & Std. Error & & & & \begin{tabular}{|l|} 
Tolerance \\
\end{tabular} & VIF \\
\hline \multirow{8}{*}{1} & (Constant) & -1.959 & .645 & & -3.039 & .004 & & \\
\hline & LN_X1 & -792 & .299 & -406 & -2.646 & .012 & .727 & 1.375 \\
\hline & LN_X2 & -197 & .341 & .080 & .576 & .568 & .885 & 1.130 \\
\hline & LN_X3 & .327 & .197 & .252 & 1.656 & .106 & .739 & 1.354 \\
\hline & $B I G$ & -121 & .392 & .044 & .308 & .760 & .827 & 1.209 \\
\hline & CPA & .037 & .539 & .011 & .069 & .946 & .687 & 1.457 \\
\hline & DCHANGE & .781 & .346 & .318 & 2.258 & .030 & .863 & 1.159 \\
\hline & ${ }_{T}^{\mathrm{LN}}$ _CEOPIC & -220 & .403 & .075 & .547 & .588 & .922 & 1.085 \\
\hline
\end{tabular}

\section{c. Uji Autokorelasi}

Nilai tabel Durbin Watson pada $\alpha=5 \%, \mathrm{n}=46, \mathrm{k}=7$ adalah $\mathrm{dL}=1,2013$ dan $\mathrm{dU}=1,8906$.

Tabel 3

\section{Uji Autokorelasi}

\begin{tabular}{|l|c|r|r|r|r|}
\hline Mo & $R$ & $\begin{array}{c}\mathrm{R} \\
\text { Squar } \\
\mathrm{del}\end{array}$ & $\begin{array}{c}\text { Adjusted } \\
\text { RqSquare }\end{array}$ & $\begin{array}{c}\text { Std. Error } \\
\text { ofqthe } \\
\text { Estimate }\end{array}$ & $\begin{array}{c}\text { Durbin- } \\
\text { Watson }\end{array}$ \\
\hline 1 & $.591^{\mathrm{a}}$ & .349 & .229 & 1.08838 & 2.164 \\
\hline
\end{tabular}

a. Predictors: (Constant), LN_CEOPICT, DCHANGE, CPA,

LN_X2, BIG, LN_X3, LN_X1

b. Dependent Variable: LN_Y

Sumber: Output SPSS diolah, 2018 
Hasil pengolahan data pada tabel 3 menunjukkan nilai DW hitung sebesar 2,164 dan nilai DW tabel sebesar 1,8906. Karena DW hitung > DW tabel maka dapat disimpulkan bahwa tidak terdapat autokorelasi.

\section{d. Uji Heterokedastisitas}

Nilai signifikan external pressure sebesar 0,846, nilai signifikan institusional ownership sebesar 0,386, nilai signifikan financia stability sebesar 0,661, nilai signifikan kualitas auditor eksternal sebesar 0,914, nilai signifikan change in auditor sebesar 0,775, nilai signifikan perubahan direksi sebesar 0,681, nilai signifikan frequent number of CEO's picture sebesar 0,995, yang artinya masing-masing nilai signifikan dari variabel independen lebih besar dari $0,05(>0,05)$. Hal ini dapat disimpulkan bahwa model regresi yang digunakan tidak terdeteksi adanya heterokedastisitas.

Tabel 4

UjiwHeterokedastisitas

\begin{tabular}{|l|c|}
\hline \multicolumn{1}{|c|}{ Variabel } & Signifikansi \\
\hline LEV & 0,846 \\
\hline OSHIP & 0,386 \\
\hline ACHANGE & 0,661 \\
\hline BIG & 0,914 \\
\hline CPA & 0,775 \\
\hline DCHANGE & 0,681 \\
\hline CEOPICT & 0,995 \\
\hline
\end{tabular}




\section{Analisis Regresi Berganda}

Tabel 5

Analisis Regresi Berganda

Coefficients $^{\mathrm{a}}$

\begin{tabular}{|c|c|c|c|c|c|c|}
\hline \multirow[t]{2}{*}{ Mod } & & \multicolumn{2}{|c|}{ Unstandardized Coefficients } & \multirow{2}{*}{$\begin{array}{c}\begin{array}{c}\text { Standardized } \\
\text { Coefficients }\end{array} \\
\text { Beta }\end{array}$} & \multirow[t]{2}{*}{$\mathrm{t}$} & \multirow[t]{2}{*}{ Sig. } \\
\hline & & B & Std. Error & & & \\
\hline \multirow{8}{*}{1} & (Constant) & -1.959 & .645 & & -3.039 & .004 \\
\hline & LN_X1 & -.792 & 299 & -.406 & -2.646 & .012 \\
\hline & LN_X2 & -.197 & 341 & -.080 & -.576 & .568 \\
\hline & LN_X3 & .327 & .197 & .252 & 1.656 & .106 \\
\hline & $B I G$ & -.121 & .392 & -.044 & -.308 & .760 \\
\hline & CPA & .037 & .539 & .011 & .069 & .946 \\
\hline & DCHANGE & .781 & .346 & .318 & 2.258 & .030 \\
\hline & LN CEOPICT & -.220 & .403 & -.075 & -.547 & .588 \\
\hline
\end{tabular}

Sumber : Output SPSS, diolah April 2018

Berdasarkan tabel diatas maka persamaan regresi sebagai berikut :

$Y=-1,959-0,792 X_{1}-0,197 X_{2}+0,327 X_{3}-0,121 X_{4}+0,037 X_{5}+0,781 X_{6}-0,220 X_{7}$

Nilai masing-masing koefisien regresi variabel independen dan model regresi linear tersebut menggambarkan Nilai koefisien regresi linier berganda sebesar -1,959. Artinya jika variabel independen proksi terdiri dari LEV (X1), OSHIP (X2), ACHANGE (X3), BIG (X4), CPA (X5), DCHANGE (X6), dan CEOPIC (X7) bernilai tetap atau konstanta, maka besarnya DA adalah -1,959. b. Nilai koefisien regresi variabel external pressure dengan proksi LEV (X1) sebesar -0,792. Artinya jika variabel lainnya tetap (konstan) maka setiap kenaikan variabel LEV 1 satuan menyebabkan DA sebesar -0,792 poin. Koefisien bernilai negatif artinya tidak terjadi hubungan searah LEV dengan DA. Artinya semakinztinggi tingkat LEV suatu perusahaan maka semakin menurun nilai Ln yang terjadi, dengan kata lain nilai DA semakin turun atau memburuk. c. Nilai koefisien regresi variabel institusional ownership dengan proksi OSHIP (X2) sebesar -0,197. Artinya jika variabel lainnya tetap (konstan) maka setiap kenaikan variabel OSHIP 1 satuanzmenyebabkan DA sebesar $-0,197$ poin. Koefisien bernilai negatif artinya tidak terjadi hubungan searah OSHIP dengan DA. Artinya semakin tinggi tingkat OSHIP suatu perusahaan maka semakin menurun nilai Ln yang terjadi, dengan kata lain nilai DA 
semakin turun atau memburuk. Nilai koefisien regresi variabel financial stability dengan proksi ACHANGE (X3) sebesar 0,327. Artinya jika variabel lainnya tetap (konstan) maka setiap kenaikan variabel ACHANGE 1 satuan menyebabkan DA sebesar 0,327 poin. Koefisien bernilai positif artinya terjadi hubungan searah ACHANGE dengan DA. Artinya semakin tinggi tingkat ACHANGE suatu perusahaan maka semakin meningkat nilai Ln yang terjadi, dengan kata lain nilai DA semakin naik atau meningkat e.Nilai koefisien regresi variabel kualitas auditor eksternal dengan proksi BIG (X4) sebesar -0,121. Artinya jika variabel lainnya tetap (konstan) maka setiap kenaikan variabel BIG 1 satuan menyebabkan DA sebesar $-0,121$ poin. Koefisien bernilai negatif artinya tidak terjadi hubungan searah BIG dengan DA. Artinya semakin tinggi tingkat BIG suatu perusahaan maka semakin menurun nilai Ln yang terjadi, dengan kata lain nilai DA semakin turun atau memburuk. f. Nilai koefisien regresi variabel change in auditor dengan proksi CPA (X5) sebesar 0,037. Artinya jika variabel lainnya tetap (konstan) maka setiap kenaikan variabel CPA 1 satuan menyebabkan DA sebesar 0,037 poin. Koefisien bernilai positif artinya terjadixhubungan searah CPA dengan DA. Artinya semakin tinggi tingkat CPA suatu perusahaan maka semakin meningkat nilai Ln yang terjadi, dengan kata lain nilai DA semakin naik atu meningkat. Nilai koefisien regresi variabel perubahan direksi dengan proksi DCHANGE (X6) sebesar 0,781. Artinya jika variabel lainnya tetap (konstan) maka setiap kenaikan variabel DCHANGE 1 satuan menyebabkan DA sebesar 0,781 poin. Koefisien bernilai positif artinya terjadi hubungan searah DCHANGE dengan DA. Artinya semakin tinggi tingkat DCHANGE suatu perusahaan maka semakin meningkat nilai Ln yang terjadi, dengan kata lain nilai DA semakin naik atau meningkat. Nilai koefisien regresi variabel frequent number of CEO's picture (X8) sebesar -0,220. Artinya jika variabel lainnya tetap (konstan) maka setiap kenaikan variabel CEOPIC 1 satuan menyebabkan DA sebesar $-0,220$ poin. Koefisien bernilai negatif artinya tidak terjadi hubungan searah CEOPIC dengan DA. Artinya semakin tinggixtingkat CEOPIC suatu perusahaan maka semakin menurun nilai Ln yang terjadi, dengan kata lain nilai DA semakin turun atau jelek. 


\section{Uji Hipotesis}

a. Uji parsial (t)

Tabel 6

Uji Parsial (t)

Coefficients $^{a}$

\begin{tabular}{|l|r|r|r|r|r|}
\hline Model & \multicolumn{2}{|c|}{$\begin{array}{c}\text { Unstandardized } \\
\text { Coefficients }\end{array}$} & $\begin{array}{c}\text { Standardized } \\
\text { Coefficients }\end{array}$ & \multicolumn{1}{c|}{$\mathrm{t}$} & \\
\cline { 2 - 5 } & \multicolumn{1}{|c|}{$\mathrm{B}$} & Std. Error & \multicolumn{1}{c|}{ Beta } & & \\
\hline \multirow{2}{*}{ (Constant) } & -1.959 & .645 & & -3.039 & .004 \\
LN_X1 & -.792 & .299 & -.406 & -2.646 & .012 \\
LN_X2 & -.197 & .341 & -.080 & -.576 & .568 \\
LN_X3 & .327 & .197 & .252 & 1.656 & .106 \\
BIG & -.121 & .392 & -.044 & -.308 & .760 \\
CPA & .037 & .539 & .011 & .069 & .946 \\
DCHANGE & .781 & .346 & .318 & 2.258 & .030 \\
LN_CEOPIC & -.220 & .403 & -.075 & -.547 & .588 \\
T & & & &
\end{tabular}

a. Dependent Variable: LN_Y

Sumber : Output SPSS, diolah April 2018

Tabel diatas menunjukkan bahwa variabel external pressure memiliki $-\mathrm{t}_{\text {hitung }}<-\mathrm{t}_{\text {tabel }}(-2,646<-2,021)$. Dengan nilai sig. $0,012<0,05$ maka Ho1 ditolak dan Ha1 diterima. Artinya external pressure berpengaruh terhadap fraudulent financial reporting. Variabel institusional ownership menunjukkan nilai $-\mathrm{t}_{\text {hitung }}>-\mathrm{t}_{\text {tabel }}(-0,576>-$ 2,021) dengan nilai sig. 0,568>0,05 maka Ho2 diterima dan Ha2 ditolak, artinya institusional ownership tidak berpengaruh terhadap fraudulent financial reporting. variabel financial stability memiliki nilai $\mathrm{t}_{\text {hitung }}<\mathrm{t}_{\text {tabel }}(1,656<2,021)$ dengan nilai sig. 0,106 $>0,05$ maka $\mathbf{H o 3}$ diterima dan Ha3 ditolak, artinya financial stability tidak berpengaruh terhadap fraudulent financial reporting. Variabel kualitas auditor eksternal memiliki $-t_{\text {hitung }}>-t_{\text {tabel }}(-0,308>-2,021)$ dengan nilai sig. 0,760 > 0,05 maka Ho4 diterima dan Ha4 ditolak, artinya kualitas auditor eksternal tidak berpengaruh terhadap fraudulent financial reporting. Variabel change in auditor memiliki $t_{\text {hitung }}<t_{\text {tabel }}(0,069<2,021)$ dengan nilai sig. 0,009<0,05 maka Ho5 diterima dan Ha5 ditolak, artinya changeiin auditor tidak berpengaruh terhadap fraudulent financial reporting. Variabel perubahan direksi memiliki $t_{\text {hitung }}>t_{\text {tabel }}(2,258>$ 2,021) dengan nilai sig. 0,030 < 0,05 maka Ho6 ditolak dan Ha6 
diterima, artinya perubahan direksi berpengaruh terhadap fraudulent financial reporting. Variabel frequent number of CEO's picture memiliki $-t_{\text {hitung }}>-t_{\text {tabel }}(-0,547>-2,021)$ dengan nilai sig. 0,588 > 0,05 maka Ho7 diterima dan Ha7 ditolak, artinya frequent number of CEO's picture tidak berpengaruh terhadap fraudulent financial reporting .

b. Uji Simultan (F)

\section{Tabel 7}

Uji Simultan

(F)

ANOVA $^{\mathrm{a}}$

\begin{tabular}{|c|c|c|c|c|c|c|}
\hline \multicolumn{2}{|c|}{ Model } & $\begin{array}{l}\text { Sum of } \\
\text { Squares }\end{array}$ & $d f$ & $\begin{array}{c}\text { Mean } \\
\text { Square }\end{array}$ & $F$ & Sig. \\
\hline \multirow{3}{*}{1} & $\begin{array}{l}\text { Regressio } \\
\mathrm{n}\end{array}$ & 24.117 & 7 & 3.445 & 2.908 & $.015^{\mathrm{b}}$ \\
\hline & Residual & 45.014 & 38 & 1.185 & & \\
\hline & Total & 69.130 & 45 & & & \\
\hline
\end{tabular}

a. Dependent Variable: LN_Y

b. Predictors: (Constant), LN_CEOPICT, DCHANGE, CPA, LN_X2, BIG, LN X3, LN X1

Sumber: Ouput SPSS, diolah April 2018

Berdasarkan tabel diatas dapat disimpulkan"bahwa external pressure, institusional ownership, financial stability, kualitaszauditor eksternal, change inzzauditor, perubahan direksi, dan frequent number of"CEO'szpicture secara simultan berpengaruh terhadap variabel dependen fraudulent financial reporting yang dilihat dari nilai $\mathrm{F}_{\text {hitung }}>$ $\mathrm{F}_{\text {tabel }}(2,908>2,34)$ dengan nilai sig lebih kecil dari $0,05(0,015<0,05)$.

c. Uji Koefisien Determinasi $\left(\mathbf{R}^{2}\right)$

Tabel 9

Koefisien $w$ Determinasiw $\left(\mathbf{R}^{2}\right)$

\begin{tabular}{|l|r|r|r|r|}
\hline $\begin{array}{l}\text { Mode } \\
\mathrm{I}\end{array}$ & $\mathrm{R}$ & $\begin{array}{c}\mathrm{R} \\
\text { Square }\end{array}$ & $\begin{array}{c}\text { AdjustedwR } \\
\text { Square }\end{array}$ & $\begin{array}{c}\text { Std.wError of } \\
\text { thewEstimate }\end{array}$ \\
\hline 1 & $.591^{\mathrm{a}}$ & .349 & .229 & 1.08838 \\
\hline
\end{tabular}


a. Predictors: (Constant), LN_CEOPICT, DCHANGE, CPA,

LN_X2, BIG, LN_X3, LN_X1

Sumber: Ouput SPSS, diolah April 2018

Berdasarkan tabel diatas dapat dilihat nilai koefisien determinasi $\left(\mathrm{R}^{2}\right)$ sebesar 0,349 atau 34,9\% yang menunjukkan kemampuan external pressure, institusional ownership, financial stability, kualitas auditor eksternal, change in auditor, perubahan direksi, dan frequent number of CEO's picture dalam menjelaskan fraudulent financial reporting sebesar $34,9 \%$. Sedangkan sisanya sebesar $65,1 \%$ dijelaskan oleh variabel lain yang tidak dimasukkan dalam model penelitian ini.

\section{KESIMPULAN}

Berdasarkan hasil penelitian dan pembahasan mengenai external pressure, institusional ownership, financial stability, kualitas auditor eksternal, change in auditor, perubahan direksi, dan frequent number of CEO's picture dapat disimpulkan bahwa external pressure berpengaruh terhadap fraudulent financial reporting. Semakin besar utang yang dimiliki perusahaan maka semakin ketat pengawasan yang dilakukan oleh kreditur, sehingga fleksibilitas atau keleluasaan manajemen untuk melakukan kecurangan laporan keuangan atau fraudulent financial reporting semakin berkurang.

Institusional ownership tidak berpengaruh terhadap fraudulent financial reporting. Hal ini dikarenakan meskipun saham yang dimiliki oleh institusi tinggi, tidak menjadi tekanan tersendiri bagi perusahaan. Bagi perusahaan tidak terdapat perbedaaan kepemilikan saham oleh institusi ataupun perorangan karena sudah menjadi kewajiban perusahaan untuk membagikan devidennya kepada pemegang saham. Deviden yang 
dibagikan kepada pemegang saham ini tidak membedakan antara saham yang dimiliki institusi, perorangan maupun manajerial, yang membedakan pembagian deviden yaitu dari jenis saham yang berupa saham biasa dan saham preferen.

Financial stability tidak berpengaruh terhadap fraudulent financial reporting. Hal ini dikarenakan tingkat pengawasan yang dilakukan oleh Dewan Komisaris sangat baik "untuk memonitor dan mengendalikan tindakan manajemen yang bertanggungjawab langsung terhadap fungsi bisnis seperti keuangan, sehingga walaupun manajemen menghadapi tekanan ketika stabilitas keuangan terancam oleh keadaan ekonomi, industri dan situasi entitas yang beroperasi tidak akan mempengaruhi terjadinya kecurangan laporan keuangan.

Kualitas auditor eksternal tidak berpengaruh terhadap fraudulent financial reporting. Hal ini dikarenakan peran auditor eksternal baik KAP Big Four maupun KAP Non Big Four memiliki peranan yang sama dalam menentukan ketidakberesan dan kekeliruan kemungkinan yang menyebabkan laporan keuangan berisi salah saji material yang berdasarkan pada standar akuntansi yang berlaku umum. Sehingga kualitas auditor eksternal tidak mempengaruhi dalam kemungkinan terjadinya fraudulent financial reporting.

Change in auditor tidak berpengaruh terhadap fraudulent financial reporting. Hal ini Karena perusahaan melakukan change in auditor bukan karena ingin mengurangi pendeteksian kecurangan laporan keuangan oleh auditor lama, tetapi dikarenakan perusahaan menaati Peraturan Pemerintah Republik Indonesia Nomor 20 Tahun 2015 pasal 11 ayat 1 yang menyatakan bahwa pemberian jasa audit atas laporan keuangan terhadap suatu entitas oleh seorang Akuntan Publik dibatasi paling lama 5 (lima) tahun buku berturut-turut. 
Perubahan direksi berpengaruh terhadap fraudulent financial reporting. Hal ini dikarenakan perubahan tersebut dapat dilakukan dengan tujuan pengalihan tanggungjawab kepada direksi yang baru melalui RUPS. Perubahan direksi tidak hanya bertujuan untuk memperbaiki kinerja, akan tetapi perubahan direksi yang dilakukan tidak sesuai ketentuan, akan memunculkan adanya indikasi fraudulent financial reporting.

Frequent number of CEO's picture tidak berpengaruh terhadap fraudulent financial reporting. Hal ini terjadi karena ditampilkannya foto CEO di dalam laporan tahunan sudah menjadi aturan perusahaan dan bukan sebagai representasi tingkat kearoganan CEO.

External pressure, institusional ownership, financial stability, kualitas auditor eksternal, change in auditor, perubahan direksi, dan frequent number of CEO's picture secara bersama-sama berpengaruh terhadap fraudulent financial reporting.

\section{REFERENSI}

Andayani, Dwi Tutut. 2010. Pengaruh Karakteristik Dewan Komisaris Independen Terhadap Manajemen Laba (Studi pada Perusahaan Manufaktur yang Terdaftar di Bursa Efek Indonesia). Skripsi. Universitas Diponegoro: Semarang.

Annisya, Mafiana. Lindrianasari. dan Asmaranti, Yuztitya. 2016. Pendeteksian Kecurangan Laporan Keuangan Menggunakan Fraud Diamond. Jurnal Bisnis dan Ekonomi ISSN: 1412-3126. Lampung. 
Ardiyani, Susmita dan Nanik S. Utaminingsih. 2015. Analisis Determinan Financial Staetement Melalui Pendekatan Fraud Triangle. Jurnal. ISSN 2252-6765.

Cressey, D. 1953. Other people's money; a study in the social psychology of embezzlement. Glencoe, IL:FreePress.

Crowe. 2011. Putting the Freud in Fraud: Why the Fraud Triangle Is No Longer Enough, IN Howart, Crowe.

Dechow, P M. Hutton, A P. Kim, J H, and Sloan, R G. 2012. Detecting Earning Management: A New Approach, Journal of Accounting Research, Vol. 50, Ed.2.

Einsenhardt, Kathleem,M. 1989. Agency Theory : An Assesment and Review. Academy of Management Review, 14, hal. 54-74.

Ghozali, Imam. 2011. Aplikasi Analisis Multivariate dengan Program SPSS. Badan Penerbit Universitas Diponegoro, Semarang.

Ghozali, Imam. 2013. Aplikasi Analisis Multivariate dengan Program SPSS. Badan Penerbit Universitas Diponegoro, Semarang.

Ghozali, Imam. 2016. Aplikasi Analisis Multivariate dengan Program SPSS. Badan Penerbit Universitas Diponegoro, Semarang.

Hanifa, Ismah Septia dan Laksito, Herry. 2015. Pengaruh Fraud Indicators Terhadap Fraudulent Financial Statement: Studi Empiris pada Perusahaan yang Listed di Bursa Efek Indonesia (BEI) Tahun 20082013. Diponegoro Journal of Accounting Vol. 04, No. 04, Hal 1-15. ISSN (online): 2337-3806.

Herviana, Ema. 2017. Fraudulent Financial Reporting: Pengujian Teori Fraud Pentagon Pada Badan Usaha Milik Negara (BUMN). Skripsi. Universitas Islam Negeri Syarif Hidayatullah: Jakarta.

Husmawati, Pera. 2017. Analisis Fraud Pentagon Dalam Mendeteksi Kecurangan Laporan Keuangan (Studi Pada Perusahaan Manufaktur yang Terdaftar di Bursa Efek Indonesia Periode 2013-2016). Tugas Akhir. Politeknik Negeri Padang. 
Kasmir. 2013. Analisis Laporan Keuangan. Edisi 1. Cetakan ke - 6. Jakarta: Rajawali Pers.

Kennedy Sihombing. 2014. Analisis Fraud Diamond dalam Mendeteksi Financial Statement Fraud : Studi empiris pada Perusahaan Manufaktur yang Terdaftar di BEI tahun 2010-2012. Diponegoro Journal of Accounting, 1-12.

Laporan Tahunan Perusahaan Property dan Real Estate. Di akses dari http://web.idx.id/ pada tanggal 30 Oktober 2017.

Lou dan Wang. 2009. Fraud Risk Factor of The Fraud Triangle Assessing The Likelihood of Fraudulent Financial Reporting. Journal of Business \& Economics Research .Vol 7 No. 2.

Norbarani, Listiana. 2012. Pendeteksian Kecurangan Laporan Keuangan Dengan Analisis Fraud Triangle Yang Diadopsi Dalam SAS No. 99. Skripsi (Tidak Dipublikasikan). Universitas Diponegoro: Semarang.

Nurbaiti, Zulvi dan Hanafi, Rustam. 2017. Analisis Pengaruh Fraud Diamond Dalam Mendeteksi Tingkat Accounting Irregularities. Jurnal Akuntansi Indonesia, Vol. 6 No. 2, Hal. 167-184.

Peraturan Pemerintah Nomor 24 Tahun 2005. Diakses dari http://www.lakip.do. am/peraturan/PP 242005 SAP.pdf pada tanggal 10 Desember 2017.

Peraturan Pemerintah Republik Indonesia Nomor 20 Tahun 2015 Pasal 11 Ayat 1. Diakses dari http://peraturan.go.id/pp/nomor-20-tahun-2015.html pada tanggal 17 Mei 2018.

Pernyataan Standar Akuntansi Keuangan. 2014. Diakses dari http://iaiglobal. or.id/v03/standar-akuntansi-keuangan/pernyataan-sak-7-psak-1penyajian-laporan-keuangan pada tanggal 16 Mei 2018.Kasmir.2008. “Manajemen Perbankan”. Edisi Revisi 2008. PT.Raja Grafindo Persada :Jakarta

Pernyataan Standar Akuntansi Keuangan. 2015. Diakses dari http://iaiglobal. or.id/v03/standar-akuntansi-keuangan/pernyataan-sak pada tanggal 16 Mei 2018. 
Priantara, Diaz. 2013. Audit Forensic dan Investigatif. Jakarta: Mitra Wacana Media Lako, Andreas. 2011. "Dekontruksi CSR \& Reformasi Paradigma Bisnis \& Akuntansi”. Erlangga : Jakarta”

Putriasih, Ketut. Herawati, Ni, T, Nyoman dan Wahyuni, Made A. 2016. Analisis Fraud Diamond Dalam Mendeteksi Financial Statement Fraud: Studi Empiris Pada Perusahaan Manufaktur yang Terdaftar di Bursa Efek Indonesia (BEI) Tahun 2013-2015. E-journal universitas Pendidikan Ganesha. Vol: 6 No: 3.

"Racmawati, Kusuma Kurnia dan Marsono. 2014. Pengaruh Faktor-Faktor Dalam Perspektif Fraud Triangle Terhadap Fraudulent Financial Reporting (Studi Kasus pada Perusahaan Berdasarkan Sanksi dari Bapepam Periode 2008-2012). Diponegoro Journal of Accounting, Vol. 3, No. 2, Hal. 1. ISSN (online): 2337-3806.

Rahmawati, et al. 2006. Pengaruh Asimetri Informasi terhadap Praktik Manajemen Laba pada Perusahaan Perbankan Publik yang Terdaftar di Bursa Efek Jakarta. Simposium Nasional Akuntansi IX. Padang.

Ratmono, Avrie dan Purwanto 2014. Dapatkah Teori Fraud Triangle Menjelaskan Kecurangan dalam Laporan Keuangan?. Simposium Nasional Akuntansi 17. Mataram Novrianto. 2012. Pengaruh Leverage, Profitabilitas, dan Ukuran Perusahaan Terhadap pengungkapan Informasi Sosial Pada Perusahaan Manufaktur Di BEI. Jurnal Ilmiah. Vol. 1. No. 1

Reviani, Dinni dan Sudantoko, Djoko. 2012. Pengaruh Struktur Kepemilikan, Ukuran Perusahaan, dan Corporate Governance terhadap Manajemen Laba. Journal ISSN 1411-1497. Prestasi Vol. 9, No. 1.

Rini, Viva Yustitia. 2012. Analisis Prediksi Potensi Risiko Fraudulent Financial Statement melalui Fraud Score Model (Studi Empiris pada Perusahaan Manufaktur yang Terdaftar di Bursa Efek Indonesia Tahun 2008 - 2010). Diponegoro Journal of Accounting, Vol. 1, No.1. “ Saputra, Anggriawan Rizal. 2016. Pengaruh Fraud Indicators Terhadap Fraudulent Financial Statement (Studi Empiris Pada Perusahaan yang 
Listed di BEI Tahun 2013-2015). Jurnal. Universitas Muhammadiyah Yogyakarta.

"Setiawati, Lilis. 2002. Manajemen Laba dan IPO di Bursa Efek Jakarta. Simposium Nasional Akuntansi 5. Semarang.

Sihombing, Samuel Kennedy dan Rahardjo, Nur Shiddiq. 2014. Analisis Fraud Diamond dalam Mendeteksi Financial Statement Fraud: Studi Empiris pada Perusahaan Manufaktur yang Terdaftar di Bursa Efek Indonesia (BEI) Tahun 2010-2012. Diponegoro Journal of Accouting Vol. 03 No. 02. ISSN (Online): 2337-3806.

Statement on Auditing Standart (SAS). No. 99. 2003. "Consideration of Fraud in a Financial Statement Audit. Journal of Accountancy. Vol. 1.

Subramanyam, K. R dan John, J. Wild. 2010. Analisis Laporan Keuangan. Buku Satu. Edisi 10. Jakarta: Salemba Empat.

Tessa, Chyntia G \& P. Harto. 2016. Fraudulent Financial Reporting : Pengujian Teori Fraud Pentagon pada Sektor Keuangan dan Perbankan di Indonesia. Simposium Nasional Akuntansi XIX. Lampung.

Ulfah dan Nuraina 2017. Pengaruh Fraud Pentagon Dalam Mendeteksi Fraudulent Financial Reporting (Studi Empiris Pada Perbankan di Indonesia yang Terdaftar di BEI). Jurnal. Forum Ilmiah Pendidikan Akuntansi Vol. 5 No. 1. Madiun. 